\title{
Synthesis of $\gamma$-Substituted Peptide Nucleic Acids: A New Place to Attach Fluorophores Without Affecting DNA Binding
}

\author{
Ethan A. Englund and Daniel H. Appella \\ Laboratory of Bioorganic Chemistry, NIDDK, NIH, Bethesda, MD 20892 and Northwestern University
}

\section{General Methods for the Synthesis of $\gamma$-Lysine(Fmoc) PNA monomers.}

General: Proton nuclear magnetic resonances $\left({ }^{1} \mathbf{H}\right.$ NMR) and ${ }^{13} \mathrm{C}$ nuclear magnetic resonances $\left({ }^{13} \mathbf{C}\right.$ NMR) were recorded in deuterated solvents on an iNOVA $(500 \mathrm{MHz})$ spectrometer. Chemical shifts are reported in parts per million ( $\mathrm{ppm}, \delta$ ) relative to tetramethylsilane $(\delta 0.00) .{ }^{1} \mathbf{H}$ NMR splitting patterns are designated as singlet (s), doublet (d), triplet (t), doublet of doublets (dd). Splitting patterns that could not be interpreted or easily visualized are designated as multiplet (m). Coupling constants are reported in Hertz (Hz). Electrospray mass spectra (ESI-MS) were obtained using a Micromass Quattro II Triple Quadrapole HPLC/MS/MS Mass Spectrometer. Highresolution mass spectra (HRMS) were obtained on a Micromass Q-Tof Ultima at the University of Illinois at Urbana-Champaign Mass Spectrometry Center. Analytical thinlayer chromatography (TLC) was carried out on Sorbent Technologies TLC plates precoated with silica gel ( $250 \mu \mathrm{m}$ layer thickness). Flash column chromatography was performed on EM Science silica gel 60 (230-400 mesh). Solvent mixtures used for TLC and flash column chromatography are reported in v/v ratios. Unless otherwise noted, all commercially available reagents and solvents were purchased from Aldrich and used without 
further purification. BocLys(Fmoc)-OH was purchased from Advanced ChemTech. Fmoc 8-amino-3,6-dioctanoic acid was purchased from Peptides International, Inc.

Dichloromethane was distilled from $\mathrm{CaH}$, and tetrahydrofuran (THF) was distilled from sodium and benzophenone prior to use. DMF was passed through activated alumina. ${ }^{1}$

Unless otherwise indicated, all reactions were performed under an inert atmosphere of $\mathrm{N}_{2}$. Glassware was dried in an oven at $180{ }^{\circ} \mathrm{C}$ for at least 2 hours prior to use.

Abbreviations: RBF, round-bottom flask; rt, room temperature; DMAP, dimethylaminopyridine; DCM, dichloromethane; DIEA, $N, N$-diisopropylethylamine; EDC, N-Ethyl-N'-(3-dimethylaminopropyl)carbodiimide; HOBT, 1-Hydroxybenzotriazole hydrate

\section{Synthesis of $\gamma$-Lys(Fmoc) PNA Monomers}
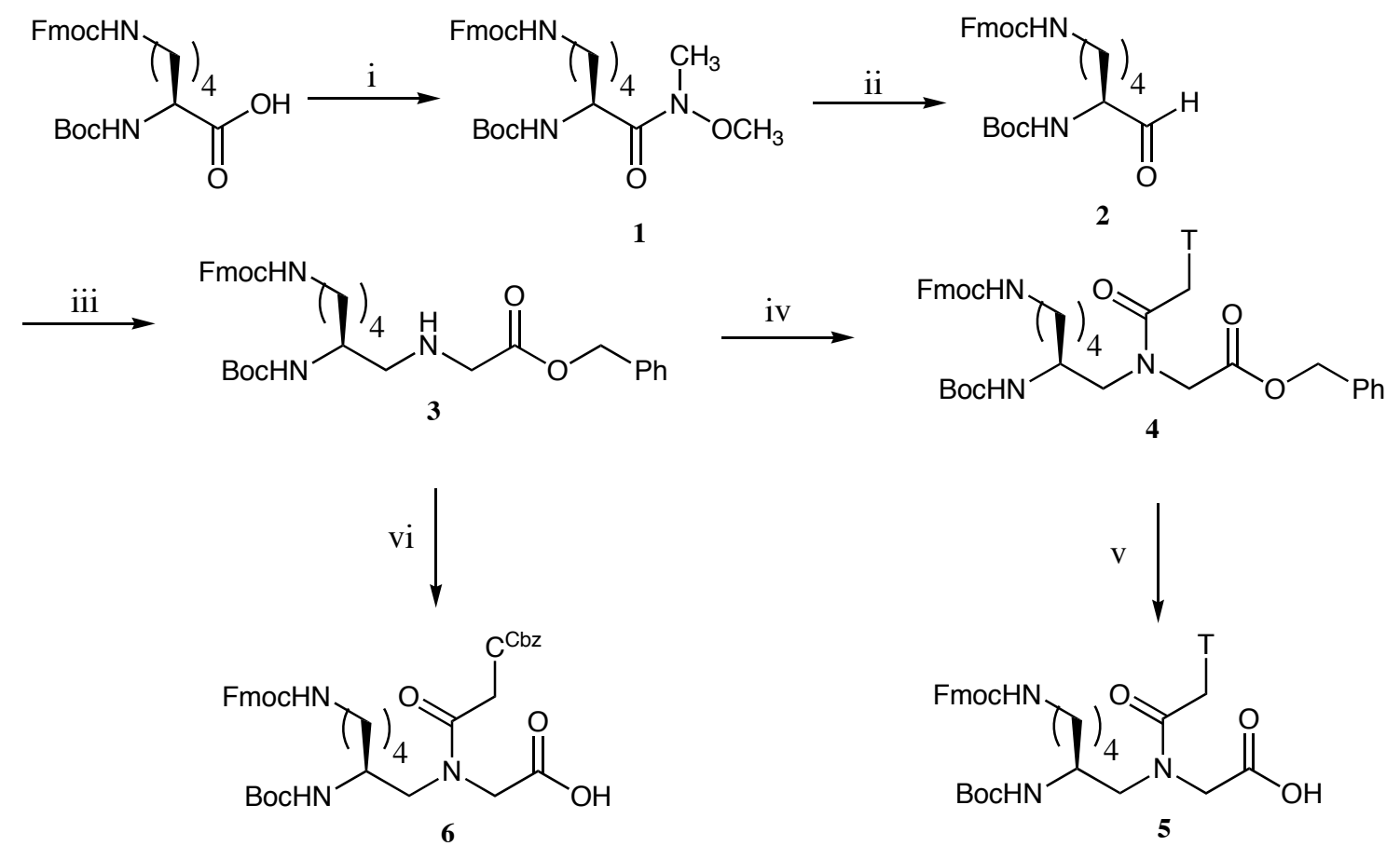

(i) N,O-dimethylhydroxylamine, EDC, DIEA, $\mathrm{CH}_{2} \mathrm{Cl}_{2}, 85 \%$; (ii) $\mathrm{LiAlH}_{4}, \mathrm{THF}, 78 \%$; (iii) benzyl glycinate, DIEA, $\mathrm{NaHB}(\mathrm{OAc})_{3}, \mathrm{CH}_{2} \mathrm{Cl}_{2}, 30 \%$; (iv) Thymine acetic acid, EDC, $\mathrm{HOBt}, \mathrm{DMF}, 82 \%$; (v) $\mathrm{H}_{2(\mathrm{~g})}, 10 \% \mathrm{Pd} / \mathrm{C}, 79 \%$; (vi) Cytosine(Cbz) acetic acid, EDC, $\mathrm{HOBt}$, DMF, followed by $\mathrm{K}_{2} \mathrm{CO}_{3}(\mathrm{aq})$, THF, $21 \%$.

Boc-Lys(Fmoc)-N(Me)OMe (1). Boc-Lys(Fmoc)-OH (5.33 g, $11.4 \mathrm{mmol})$ was dissolved 
in dry DCM (66 mL) in a $100 \mathrm{~mL}$ RBF. EDC (2.72 g, $14.2 \mathrm{mmol})$ and HOBT (1.92 g, $14.2 \mathrm{mmol}$ ) were added to the solution. The reaction mixture was then cooled to $0{ }^{\circ} \mathrm{C}$ with an ice bath and DIEA $(2.5 \mathrm{~mL}, 14.3 \mathrm{mmol})$ was added slowly to the stirring solution. The solution was allowed to stir for five minutes. N,O-

Dimethylhydroxylamine hydrochloride salt $(1.38 \mathrm{~g}, 14.2 \mathrm{mmol})$ was added to the solution along with more DIEA $(2.5 \mathrm{~mL}, 14.3 \mathrm{mmol})$ and the ice bath was removed. The reaction mixture was allowed to stir for 12 hours. The solution was then transferred to a seperatory funnel and washed with $1 \mathrm{M} \mathrm{HCl}(2 \times 30 \mathrm{~mL})$, saturated $\mathrm{NaHCO}_{3}$ solution (2 x $30 \mathrm{~mL})$ and saturated $\mathrm{NaCl}$ solution $(2 \times 30 \mathrm{~mL})$. The organic layer was dried over $\mathrm{Na}_{2} \mathrm{SO}_{4}$ and evaporated under reduced pressure to afford $5.74 \mathrm{~g}$ (99\% yield) of the desired product as a colorless, viscous oil. ${ }^{1} \mathrm{H} \mathrm{NMR}\left(\mathrm{CDCl}_{3}, 500 \mathrm{MHz}\right): \delta 7.77(\mathrm{~d}, 2 \mathrm{H}$,

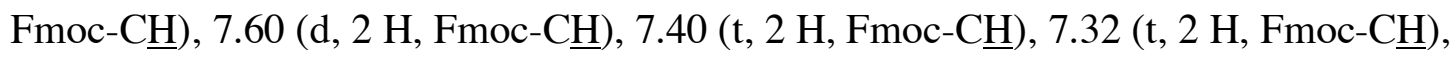
$5.22(\mathrm{~d}, 1 \mathrm{H}, \mathrm{N} \underline{\mathrm{H}}), 4.88(\mathrm{~s}, 1 \mathrm{H}, \mathrm{N} \underline{\mathrm{H}}), 4.68$ (s, $\left.1 \mathrm{H}, \mathrm{HN}-\mathrm{C} \underline{\mathrm{H}}\left(\mathrm{CH}_{2}\right)-\mathrm{CO}\right), 4.39$ (d, $2 \mathrm{H}, \mathrm{O}-$ $\left.\mathrm{C}_{2}-\mathrm{CH}(\mathrm{CH})_{2}\right), 4.21\left(\mathrm{t}, 1 \mathrm{H}, \mathrm{O}-\mathrm{CH}_{2}-\mathrm{C} \underline{\mathrm{H}}(\mathrm{CH})_{2}\right), 3.77\left(\mathrm{~s}, 3 \mathrm{H}, \underline{\mathrm{CH}}_{3}\right), 3.20(\mathrm{~s}, 3 \mathrm{H}, \mathrm{N}-$ $\left.\underline{\mathrm{CH}}_{3}\right), 3.20\left(\mathrm{~m}, 2 \mathrm{H}, \mathrm{NH}-\underline{\mathrm{H}}_{2}-\mathrm{CH}_{2}\right), 1.73-1.33\left(\mathrm{~m}, 6 \mathrm{H}, \mathrm{CH}-\underline{\mathrm{H}}_{2}-\mathrm{C}_{2}-\mathrm{C}_{2}-\mathrm{CH}_{2}\right), 1.43$ (s, $9 \mathrm{H}$, tert-butly-C $\left.\underline{\mathrm{H}}_{3}\right) ;{ }^{13} \mathrm{C} \mathrm{NMR}\left(\mathrm{CDCl}_{3}, 126 \mathrm{MHz}\right): \delta 173.3,156.7,155.9,144.2,141.5$, $127.9,127.3,125.3,120.2,79.8,66.7,61.8,50.3,47.5,41.0,32.8,32.3,29.5,28.6,22.7$ Boc-Lys(Fmoc)-CHO (2). Boc-Lys(Fmoc)-N(Me)OMe (2.33 g, 5.5 mmol) was dissolved in a minimal amount of $\mathrm{CH}_{2} \mathrm{Cl}_{2}$ to form a gray film. The viscous film was then dissolved in dry THF $(60 \mathrm{~mL})$ in a $100 \mathrm{~mL} \mathrm{RBF}$ and cooled to $0{ }^{\circ} \mathrm{C}$ with an ice bath. Lithium aluminum hydride $(365 \mathrm{mg}, 9.60 \mathrm{mmol}$ ) was added gradually over 45 seconds to the stirring solution. The reaction was monitored via TLC. After 45 minutes, the reaction mixture was quenched with saturated $\mathrm{NaHSO}_{4}$ solution $(20 \mathrm{~mL})$ and allowed to 
stir for 10 minutes. The solution was then transferred to a separatory funnel and washed with EtOAc $(3 \times 55 \mathrm{~mL})$. The combined organic layers were washed with $1 \mathrm{M} \mathrm{HCl}(2 \mathrm{x}$ $50 \mathrm{~mL})$, saturated $\mathrm{NaHCO}_{3}$ solution $(2 \times 50 \mathrm{~mL})$, water $(2 \times 50 \mathrm{~mL})$ and saturated $\mathrm{NaCl}$ solution $(2 \times 50 \mathrm{~mL})$. The organic layer was dried over $\mathrm{Na}_{2} \mathrm{SO}_{4}$ and evaporated under reduced pressure to afford $1.70 \mathrm{~g}$ (85 \% yield) of Boc-Lys(Fmoc)-CHO as white solid.

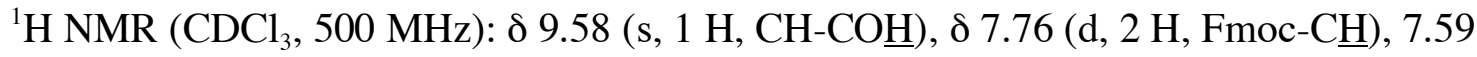

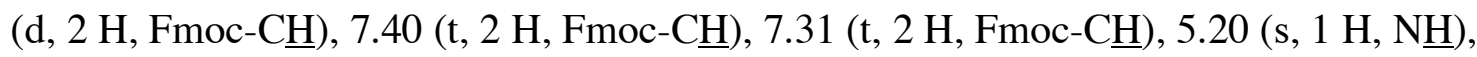
4.89 (s, $1 \mathrm{H}, \mathrm{N} \underline{\mathrm{H}}), 4.41\left(\mathrm{~d}, 2 \mathrm{H}, \mathrm{O}-\mathrm{CH}_{2}-\mathrm{CH}(\mathrm{CH})_{2}\right), 4.21\left(\mathrm{~m}, 1 \mathrm{H}, \mathrm{O}-\mathrm{CH}_{2}-\mathrm{C} \underline{\mathrm{H}}(\mathrm{CH})_{2}\right)$, $4.21\left(\mathrm{~m}, 1 \mathrm{H}, \mathrm{HN}-\mathrm{CH}\left(\mathrm{CH}_{2}\right)-\mathrm{CO}\right), 3.19$ (d, $\left.2 \mathrm{H}, \mathrm{NH}-\mathrm{CH}_{2}-\mathrm{CH}_{2}\right), 1.73-1.33$ (m, $6 \mathrm{H}, \mathrm{CH}-$ $\left.\underline{\mathrm{CH}}_{2}-\underline{\mathrm{CH}}_{2}-\underline{\mathrm{CH}}_{2}-\mathrm{CH}_{2}\right), 1.44\left(\mathrm{~s}, 9 \mathrm{H}\right.$, tert-butyl- $\left.\underline{\mathrm{CH}}_{3}\right)$

BocLys(Fmoc)-PNA Backbone (3). Boc-Lys(Fmoc)-CHO (2.45 g, 5.4 mmol) and benzyl glycinate hydrocholide salt $(2.01 \mathrm{mg}, 5.96 \mathrm{mmol})$ were dissolved in dry DCM (30 $\mathrm{mL})$ in a $100 \mathrm{~mL}$ RBF. DIEA (1.04 mL) was added slowly to the stirring solution, which was then allowed to stir for 10 minutes. Triacetoxyborohydride $(1.60 \mathrm{~g}, 7.56 \mathrm{mmol})$ was then added. The cloudy reaction mixture was allowed to stir for 1 hour and 45 minutes. The reaction was then quenched with saturated $\mathrm{Na}_{2} \mathrm{CO}_{3}(15 \mathrm{~mL})$ and stirred for 10 minutes. The mixture was washed with DCM $(2 \times 30 \mathrm{~mL})$ and the combined organic layers were dried over $\mathrm{Na}_{2} \mathrm{SO}_{4}$. Evaporation afforded a clear, colorless oil. The oil was purified via column chromatography (EtOAc, $\mathrm{rf}=0.5)$ to afford $1.96 \mathrm{~g}(60 \%$ yield $)$ of the desired product as a clear, colorless oil. ${ }^{1} \mathrm{H}$ NMR $\left(\mathrm{CDCl}_{3}, 500 \mathrm{MHz}\right): \delta 7.74(\mathrm{~d}, 2 \mathrm{H}$,

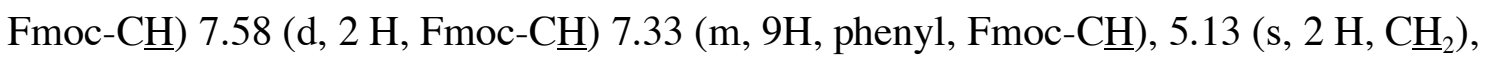
$5.11(\mathrm{~s}, 1 \mathrm{H}, \mathrm{N} \underline{\mathrm{H}}), 4.82(\mathrm{~d}, 1 \mathrm{H}, \mathrm{N} \underline{\mathrm{H}}), 4.38\left(\mathrm{~m}, 2 \mathrm{H}, \mathrm{O}-\mathrm{C}_{2}-\mathrm{CH}\right), 4.19$ (t, $1 \mathrm{H}, \mathrm{CH}_{2}-\mathrm{C} \underline{\mathrm{H}}-$ $\left.(\mathrm{CH})_{2}\right), 3.62\left(\mathrm{~s}, 1 \mathrm{H}, \mathrm{NH}-\mathrm{C} \underline{\mathrm{H}}-\left(\mathrm{CH}_{2}\right)_{2}\right), 3.41\left(\mathrm{dd}, 2 \mathrm{H}, \mathrm{NH}-\mathrm{CH}_{2}-\mathrm{CO}\right), 3.16(\mathrm{~d}, 2 \mathrm{H}$, 
NHFmoc- $\left.\underline{\mathrm{H}}_{2}-\mathrm{CH}_{2}\right), 2.61\left(\mathrm{~m}, 2 \mathrm{H}, \mathrm{NH}-\underline{\mathrm{C}}_{2}-\mathrm{CH}(\mathrm{NHBoc})-\mathrm{CH}_{2}\right), 1.39\left(\mathrm{~m}, 6 \mathrm{H}, \mathrm{CH}-\underline{\mathrm{C}}_{2}-\right.$ $\left.\mathrm{C}_{2}-\mathrm{C}_{2}-\mathrm{CH}_{2}\right), 1.43$ (s, $9 \mathrm{H}$, tert-butly- $\left.\underline{\mathrm{CH}}_{3}\right) ;{ }^{13} \mathrm{C} \mathrm{NMR}\left(\mathrm{CDCl}_{3}, 126 \mathrm{MHz}\right): \delta$ 172.64, $156.79,156.24,144.28,141.53,135.80,128.86,128.66,128.60,127.90,127.29,125.33$, $120.20,79.40,66.79,66.72,53.15,51.12,50.37,47.52,40.96,33.03,29.80,28.67,23.18$. $\boldsymbol{\gamma}$-Lys(Fmoc) PNA Thymine Monomer Ester (4). BocLys(Fmoc)-PNA Backbone (570 $\mathrm{mg}, 0.94 \mathrm{mmol})$, thymine acetic acid (226 mg, $1.23 \mathrm{mmol})$ and HOBT (7 mg, $0.05 \mathrm{mmol})$ were dissolved in dry DMF (20 mL). EDC hydrochloride salt (272 mg, $1.42 \mathrm{mg})$ was added to the stirring solution. After 36 hours, the DMF solution was added to $\mathrm{H}_{2} \mathrm{O}$ (40 $\mathrm{mL}$ ) forming a white precipitate. The solution was then washed with EtOAc $(3 \times 40 \mathrm{~mL})$. The combined organic layers were washed with $1 \mathrm{M} \mathrm{HCl}(2 \times 40 \mathrm{~mL})$, saturated $\mathrm{NaHCO}_{3}$ $(2 \times 40 \mathrm{~mL})$, water $(2 \times 40 \mathrm{~mL})$, and saturated $\mathrm{NaCl}(2 \times 40 \mathrm{~mL})$. The organic layer was dried over $\mathrm{Na}_{2} \mathrm{SO}_{4}$ and evaporated under reduced pressure to afford $593 \mathrm{mg}$ (82\% yield) of $\gamma$-Lys(Fmoc) PNA Thymine Monomer Ester as a white solid. ${ }^{1} \mathrm{H}$ NMR (DMSO, 500 MHz) Major Rotomer Only: $\delta 11.31$ (s, 1 H, Thymine-Cㅌ) $\delta 7.88$ (d, 2 H, Fmoc-Cㅂ)

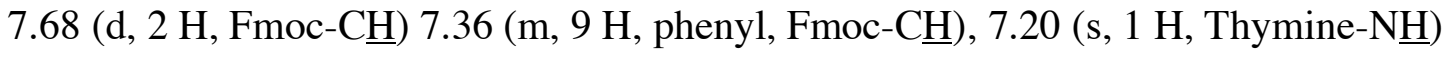
5.12 (s, 2 H, O-C $\underline{\mathrm{H}}_{2}$-phenyl), 4.70 (dd, $2 \mathrm{H}, \mathrm{OC}-\mathrm{C}_{2}-$ Thymine), 4.28 (s, $2 \mathrm{H}, \mathrm{O}-\mathrm{C}_{2}{ }_{2}^{-}$ $\mathrm{CH}), 4.20$ (s, $\left.1 \mathrm{H}, \mathrm{CH}_{2}-\mathrm{C} \underline{\mathrm{H}}-(\mathrm{CH})_{2}\right), 4.09$ (m, $\left.2 \mathrm{H}, \mathrm{N}-\mathrm{C}_{2}-\mathrm{CO}\right), 3.66$ (s, $1 \mathrm{H}, \mathrm{NH}-\mathrm{C} \underline{\mathrm{H}}-$ $\left.\left(\mathrm{CH}_{2}\right)_{2}\right), 3.32\left(\mathrm{~m}, 2 \mathrm{H}, \mathrm{N}-\underline{\mathrm{H}}_{2}-\mathrm{CH}(\mathrm{NHBoc})-\mathrm{CH}_{2}\right), 2.97$ (m, $\left.2 \mathrm{H}, \mathrm{NHFmoc}-\mathrm{C}_{2}-\mathrm{CH}_{2}\right)$, $1.74\left(\mathrm{~s}, 3 \mathrm{H}\right.$, Thymine-C$\left.\underline{\mathrm{H}}_{3}\right) 1.35$ (s, $9 \mathrm{H}$, tert-butyl- $\left.\underline{\mathrm{H}}_{3}\right), 1.35\left(\mathrm{~m}, 6 \mathrm{H}, \mathrm{CH}-\underline{\mathrm{CH}}_{2}-\underline{\mathrm{CH}}_{2}{ }^{-}\right.$ $\left.\mathrm{C}_{2}-\mathrm{CH}_{2}\right) ;{ }^{13} \mathrm{C}$ NMR (DMSO, $126 \mathrm{MHz}$ ): $\delta 169.5,168.2,165.0,156.7,156.3,151.6$, 144.6, 142.4, 141.4, 136.5, 129.2, 129.1, 128.7, 128.5, 128.3, 127.7, 125.8, 120.8, 108.9, 78.6, 66.5, 65.8, 52.3, 49.3, 48.8, 48.4, 47.4, 31.7, 29.9, 28.8, 23.6, 12.6; HRMS (ESIMS $m / z$ ) mass calcd for $\mathrm{C}_{42} \mathrm{H}_{49} \mathrm{~N}_{5} \mathrm{O}_{9}[\mathrm{M}+\mathrm{H}]+$, , 768.3564, found 768.3586 
$\gamma$-Lys(Fmoc) Thymine Monomer (5). $\gamma$-Lys(Fmoc) Thymine Monomer Benzyl Ester (126 mg, $0.16 \mathrm{mmol})$, was dissolved in of $\mathrm{MeOH}(15 \mathrm{~mL}) . \mathrm{Pd} / \mathrm{C}(30 \mathrm{mg})$ was added slowly to the solution over 2 minutes. Solution was placed under an atmosphere of $\mathrm{H}_{2}$ (balloon pressure) for 12 hours, stirring vigorously. The $\mathrm{Pd} / \mathrm{C}$ was filtered off with celite and the solvent was evaporated under reduced pressure to afford $86 \mathrm{mg}$ (79 \% yield) of $\gamma$ Lys(Fmoc) Thymine Monomer Acid as a flakey, off-white solid. ${ }^{1} \mathrm{H}$ NMR (DMSO, 500

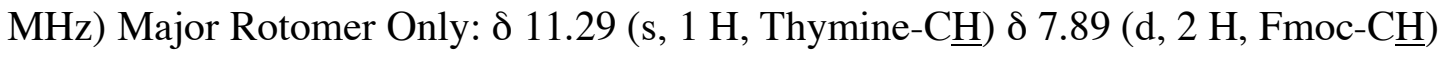

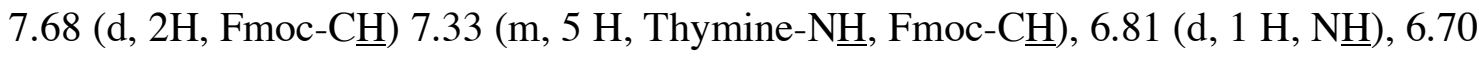
(d, $1 \mathrm{H}, \mathrm{N} \underline{\mathrm{H}}), 4.66\left(\mathrm{dd}, 2 \mathrm{H}, \underline{\mathrm{CH}}_{2}\right), 4.28\left(\mathrm{~s}, 2 \mathrm{H}, \mathrm{O}-\mathrm{C}_{2}-\mathrm{CH}\right), 4.20$ (s, $1 \mathrm{H}, \mathrm{CH}_{2}-\mathrm{C} \underline{\mathrm{H}}-$ $\left.(\mathrm{CH})_{2}\right), 3.96\left(\mathrm{~m}, 2 \mathrm{H}, \mathrm{N}-\mathrm{Cl}_{2}-\mathrm{CO}\right), 3.66$ (s, $\left.1 \mathrm{H}, \mathrm{NH}-\mathrm{C} \underline{\mathrm{H}}-\left(\mathrm{CH}_{2}\right)_{2}\right), 3.32$ (m, $2 \mathrm{H}, \mathrm{NHFmoc}-$ $\left.\underline{\mathrm{CH}}_{2}-\mathrm{CH}_{2}\right), 2.96\left(\mathrm{~m}, 2 \mathrm{H}, \mathrm{N}-\underline{\mathrm{H}}_{2}-\mathrm{CH}(\mathrm{NHBoc})-\mathrm{CH}_{2}\right), 1.74$ (s, $3 \mathrm{H}$, Thymine- $\left.\underline{\mathrm{H}}_{3}\right) 1.37$ (s, $9 \mathrm{H}$, tert-butly- $\left.\underline{\mathrm{H}}_{3}\right), 1.37$ (m, $\left.6 \mathrm{H}, \mathrm{CH}-\mathrm{C}_{2}-\underline{\mathrm{C}}_{2}-\mathrm{C}_{2}-\mathrm{CH}_{2}\right)$; HRMS (ESI-MS m/z) mass calcd for $\mathrm{C}_{35} \mathrm{H}_{43} \mathrm{~N}_{5} \mathrm{O}_{9}[\mathrm{M}+\mathrm{H}]+, 678.3094$, found 678.3140

$\boldsymbol{\gamma}$-Lys(Fmoc) Cytosine(Cbz) Monomer Acid (6). BocLys(Fmoc)-PNA Backbone (142 $\mathrm{mg}, 0.23 \mathrm{mmol})$, cytosine acetic acid ${ }^{2}(95 \mathrm{mg}, 0.31 \mathrm{mmol})$ and HOBT (2 mg, $\left.0.01 \mathrm{mmol}\right)$ were dissolved in dry DMF (5 mL). EDC hydrochloride salt (68 mg, $0.36 \mathrm{mg}$ ) was added to stirring solution. After 36 hours, the DMF solution was added to $\mathrm{H}_{2} \mathrm{O}(10 \mathrm{~mL})$ forming a white precipitate. The solution was then washed with EtOAc $(3 \times 10 \mathrm{~mL})$. The combined organic layers were washed with $1 \mathrm{M} \mathrm{HCl}(2 \times 10 \mathrm{~mL})$, saturated $\mathrm{NaHCO}_{3}$ $(2 \times 10 \mathrm{~mL})$, water $(2 \times 10 \mathrm{~mL})$, and saturated $\mathrm{NaCl}(2 \times 10 \mathrm{~mL})$. The organic layer was dried over $\mathrm{Na}_{2} \mathrm{SO}_{4}$ and evaporated under reduced pressure to afford $157 \mathrm{mg}$ of crude $\gamma$ Lys(Fmoc) PNA Cytosine Monomer Benzyl Ester as a white solid. Mass spec and ${ }^{1} \mathrm{H}$ NMR confirmed presence of product. The crude product was then dissolved in THF (8 
$\mathrm{mL})$. A solution of saturated $\mathrm{K}_{2} \mathrm{CO}_{3}(20 \mathrm{~mL})$ was added slowly to the solution over 2 minutes. The ice bath was removed and the solution was allowed to stir for an additional 48 hours. The solution was concentrated, diluted with a solution of saturated $\mathrm{K}_{2} \mathrm{CO}_{3}(10$ $\mathrm{mL})$ and washed with $\mathrm{Et}_{2} \mathrm{O}(1 \times 5 \mathrm{~mL})$. The reaction was then made acidic $(\mathrm{pH}=1-2)$ with $3 \mathrm{M} \mathrm{HCl}$ forming a white precipitate. The solution was washed with EtOAc $(4 \times 20$ $\mathrm{mL})$. The combined organic layers were dried over $\mathrm{Na}_{2} \mathrm{SO}_{4}$ and evaporated under reduced pressure. Trituration with hexanes and decanting afforded $42 \mathrm{mg}$ (21\% yield over 2 steps) of $\gamma$-Lys(Fmoc) Cytosine(Cbz) Monomer acid as a flakey, off-white solid. LRMS (ESI-MS $m / z$ ) mass calcd for $\mathrm{C}_{42} \mathrm{H}_{48} \mathrm{~N}_{6} \mathrm{O}_{10} \quad[\mathrm{M}+\mathrm{H}]+$, 797.35, found 797.4 General Procedure for Manual Solid Phase Synthesis of Peptide Nucleic Acids (PNAs)

General: aegPNA monomers were purchased from Applied Biosystems. Kaiser test solutions were purchased from Fluka. HATU and Boc-Lys-(2-Cl-Z)-OH were purchased from Advanced Chemtech. All other chemicals were purchased from Sigma-Aldrich. Abbreviations: (DCM), dichloromethane; (DIEA), N,N-diisopropylethyl amine; (NMP), 1-Methyl-2-pyrrolidinone; (HATU), O-(7-Azabenzotriazol-1-yl)-N,N,N',N'tetramethyluronium hexafluorophosphate; (MDCHA), N-Methyldicyclohexylamine; (DMF), N,N-Dimethylformamide; (HBTU), O-(Benzotriazol-1-yl)-N,N,N',N'tetramethyluronium hexafluorophosphate; $\left(\mathrm{Ac}_{2} \mathrm{O}\right)$, acetic anhydride; (TFMSA), Trifluoromethanesulfonic acid; (TFA), Trifluoroacetic acid; (Fmoc)mini-PEG, Fmoc 8amino 3,6 dioctanoic acid Note on resin washes: All washes used at least enough solution to cover the resin $(\sim 1.5$ $\mathrm{mL}$ for $50 \mathrm{mg}$ resin, and $\sim 5 \mathrm{~mL}$ for $1 \mathrm{~g}$ resin). Values in parentheses describe the number of times the resin is washed with the indicated solution, and the agitation time for each wash. For example, $(4 \mathrm{x}-30 \mathrm{~s})$ indicates four washes, with each having an agitation time of 30 seconds and each followed by draining under vacuum. If no time or number of 
repetitions is indicated, a single wash and/or a five second agitation period is used.

1. Downloading Resin

Methyl benzhydryl amine (MBHA) resin (1.0 g, 0.3 mmol active sites/gram) is downloaded to $0.1 \mathrm{mmol} / \mathrm{g}$ with Boc-Lys-(2-Cl-Z)-OH. The resin is first swelled in DCM for anytime between 1 and 12 hours. The following solutions are prepared: 0.2 M Boc-Lys-(2-ClZ)-OH in NMP (A), 0.2 M HATU in NMP (B), and 0.5 M DIEA in NMP (C). These solutions are then combined appropriately to give two additional solutions: $0.45 \mathrm{~mL}$ of $\mathrm{A}+$ $0.46 \mathrm{~mL}$ of $\mathrm{C}+1.59 \mathrm{~mL}$ NMP (Solution 1), and $0.55 \mathrm{~mL}$ of B $+1.95 \mathrm{~mL}$ NMP (Solution 2). Solutions 1 and 2 are pre-mixed for one minute and then added to the resin.

The resin is agitated with a mechanical shaker for one hour and then drained under vacuum. The resin is subsequently washed with DMF (4x), DCM (4x), 5\% DIEA in DCM (1x-30s), and again with DCM (4x). The remaining active sites are then capped with a 1:2:2 solution of $\mathrm{Ac}_{2} \mathrm{O}$ :NMP:pyridine for 1.5 hours. This is followed by washes with DCM $(2 \mathrm{x}-5 \mathrm{~s})$ and a qualitative Kaiser 1 test to confirm that no primary amines remain. Resin is then washed with DCM (2x) and allowed to dry under vacuum for 30-60 minutes. Downloaded resin is stored in a dessicator until further use.

2. aegPNA Synthesis ${ }^{4}$

The following is a representative coupling cycle for one PNA monomer. Downloaded resin (50 mg) is swelled in DCM for $1 \mathrm{hr}$. The solvent is drained under vacuum and a solution of $5 \% \mathrm{~m}$-cresol in TFA is added to the resin. The resin is shaken for 4 minutes, and the solution is removed under vacuum. (Note: The TFA deprotection is repeated three times for deprotection of the lysine residue and then twice for every subsequent monomer.) This is followed by subsequent washes with DCM, DMF $(1 \mathrm{x}-5 \mathrm{~s}, 1 \mathrm{x}-30 \mathrm{~s}, 1 \mathrm{x}-$ $5 \mathrm{~s})$, DCM $(2 \mathrm{x}-5 \mathrm{~s})$, and pyridine $(2 \mathrm{x}-5 \mathrm{~s})$. A Kaiser ${ }^{3}$ test is performed to confirm deprotection. Upon positive Kaiser test, $150 \mu \mathrm{L}$ of a $0.4 \mathrm{M}$ solution of PNA monomer in NMP is pre-mixed with $150 \mu \mathrm{L}$ of $0.8 \mathrm{M}$ MDCHA in pyridine and $300 \mu \mathrm{L}$ of $0.2 \mathrm{M}$ HBTU in DMF for one minute. This solution is then added to the resin and agitated for 
30 minutes. Following coupling, the resin was drained under vacuum and washed with DMF, 5\% DIEA/DCM (1x-30s) and DCM (2x-5s). Again, a qualitative Kaiser $^{3}$ test is performed and, if negative, the resin is capped with a 1:25:25 mixture of $\mathrm{Ac}_{2} \mathrm{O}$ : NMP: pyridine (2x-2min). (Note: If the Kaiser test is positive, the coupling cycle is repeated, beginning with the pyridine washes.) The capping step is followed by washes with DCM, $20 \%$ piperidine/DMF and finally DCM (1x-5s, $1 x-30 s, 1 x-5 s)$. This cycle is then repeated iteratively until the oligomer is complete on resin.

3. $\gamma$-Lysine PNA Synthesis/ Attachment of Linker and Fluorophore The following is a representative coupling cycle for $1 \gamma$-lysine/linker/fluorophore PNA monomer. The resin is washed with a solution of $5 \% \mathrm{~m}$-cresol in TFA ( $3 \mathrm{x}-4 \mathrm{~min})$ and removed under vacuum. This is followed by subsequent washes with DCM, DMF $(1 \mathrm{x}-5 \mathrm{~s}$, $1 \mathrm{x}-30 \mathrm{~s}, 1 \mathrm{x}-5 \mathrm{~s})$, DCM $(2 \mathrm{x}-5 \mathrm{~s})$, and pyridine $(2 \mathrm{x}-5 \mathrm{~s})$. A Kaiser ${ }^{3}$ test is performed to confirm deprotection. Upon positive Kaiser $^{3}$ test, $150 \mu \mathrm{L}$ of a $0.4 \mathrm{M}$ solution of $\gamma$-lysine PNA monomer in NMP is pre-mixed with $150 \mu \mathrm{L}$ of DIEA and $300 \mu \mathrm{L}$ of $0.2 \mathrm{M}$ HBTU in DMF for one minute. This solution is then added to the resin and agitated for 60 minutes. Following coupling, the resin is drained and washed with DMF, 5\% DIEA/DCM (1x-30s) and DCM (2x-5s). Again, a qualitative Kaiser $^{3}$ is performed and, if negative, the resin is capped with a 1:25:25 mixture of $\mathrm{Ac}_{2} \mathrm{O}$ : NMP: pyridine (2x-2min). (Note: If the Kaiser test is positive, the coupling cycle is repeated, beginning with the pyridine washes.) The capping step is followed by washes with DCM, DMF and finally DCM (1x-5s, 1x-30s, 1x-5s). The resin is then washed with $20 \%$ piperdine in DMF $(3 \mathrm{x}-4 \mathrm{~min})$ to remove the Fmoc protecting group on the $\gamma$-side chain. Upon positive Kaiser test, $150 \mu \mathrm{L}$ of a $0.4 \mathrm{M}$ solution of (Fmoc)mini-PEG in NMP is pre-mixed with $150 \mu \mathrm{L}$ of DIEA and $300 \mu \mathrm{L}$ of $0.2 \mathrm{M} \mathrm{HBTU}$ in DMF for one minute. This solution is then added to the resin and agitated for 60 minutes. Following coupling, the resin is drained and washed with DMF, 5\% DIEA/DCM $(1 \mathrm{x}-30 \mathrm{~s})$ and DCM $(2 \mathrm{x}-5 \mathrm{~s})$. Again, a qualitative Kaiser $^{3}$ is performed and, if negative, the 
resin is capped with a 1:25:25 mixture of $\mathrm{Ac}_{2} \mathrm{O}$ : NMP: pyridine (2x-2min). The capping step is followed by washes with DCM, DMF and finally DCM (1x-5s, 1x-30s, 1x-5s). The resin is then washed with $20 \%$ piperdine in DMF (3x-4min). Upon positive Kaiser test, $150 \mu \mathrm{L}$ of a $0.4 \mathrm{M}$ solution of 9-fluoreneacetic acid in NMP is pre-mixed with $150 \mu \mathrm{L}$ of DIEA and $300 \mu \mathrm{L}$ of $0.2 \mathrm{M}$ HBTU in DMF for one minute. This solution is then added to the resin and agitated for 60 minutes. Following coupling, the resin is drained and washed with DMF, 5\% DIEA/DCM (1x-30s) and DCM (2x-5s). Again, a qualitative Kaiser $^{3}$ is performed and, if negative, the resin is capped with a 1:25:25 mixture of $\mathrm{Ac}_{2} \mathrm{O}$ : NMP: pyridine $(2 \mathrm{x}-2 \mathrm{~min})$. The capping step is followed by washes with DCM, $20 \%$ piperdine in DMF and finally DCM (1x-5s, 1x-30s, 1x-5s).

\section{Cleavage of PNA from Resin}

Cleavage from the resin is accomplished under acidic conditions. First, the resin is washed with TFA (2x-4min) and drained under vacuum. Next, $750 \mu \mathrm{L}$ of a solution cooled to $0{ }^{\circ} \mathrm{C}$ consisting of $75 \mu \mathrm{L}$ thioanisole, $75 \mu \mathrm{L}$ m-cresol, $150 \mu \mathrm{L}$ TFMSA, and 450

$\mu \mathrm{L}$ TFA is added to the resin and agitated for one hour. The resulting solution is collected using positive $\mathrm{N}_{2}$ pressure to force liquid through the fritted vessel. Another $750 \mu \mathrm{L}$ portion of cleavage solution is added. After an additional hour of agitation, cleavage solutions are combined in a glass vial and volatiles are removed by passing a stream of dry nitrogen over the product to afford a yellow/brown oil.

\section{Crude PNA Isolation}

The resulting oil is partitioned between five $2.0 \mathrm{~mL}$ microcentrifuge tubes using a micropipeter, to typically yield $100-150 \mu \mathrm{L}$ of the oil per tube. A 10 -fold excess (by volume) of diethyl ether is added to each tube. The solutions are mixed by vortexing until the brown color no longer remains and a cloudy white precipitate forms. The solutions are then placed on dry ice for ten minutes. This is followed by centrifugation ( $5 \mathrm{~min}$ at 7000 rpm) and removal of solvent via decanting or pipeting to yield a white solid as the crude PNA product. The ether precipitation cycle is repeated four times with the following dry ice 
incubation times; $(2 \mathrm{x}-5 \mathrm{~min}),(2 \mathrm{x}-2 \mathrm{~min})$. Repeating the cycle twice more with no dry ice incubation completes crude PNA isolation. After decanting the final ether wash, residual solvent is removed by passing a stream of $\mathrm{N}_{2}$ over the crude PNA product.

\section{PNA Purification and Characterization}

All peptide nucleic acid (PNA) oligomers were purified on reverse-phase HPLC with UV detection at $260 \mathrm{~nm}$. VYDEK C18 (d=10 mm, l=250 mm, 5 microns) semi-prep columns were utilized, eluting with $0.05 \%$ TFA in water (Solution A) and $0.05 \%$ TFA in acetonitrile (Solution B). An elution gradient of $100 \%$ A to $100 \%$ B over 60 minutes at flow rate 5.05 $\mathrm{mL} / \mathrm{min}$. PNAs were characterized by mass spectroscopy, using a PerSeptive Biosystems Voyager DE MALDI-TOF system with 2',4',6'-trihydroxyacetophenone monohydrate matrix. Mass spectra were acquired using a $\mathrm{N}_{2}$ laser (337 nm wavelength, $5 \mathrm{~ns}$ pulse), with at least 100 shots per sample. All PNA oligomers gave molecular ions consistent with the final product.

PNA $1 \mathrm{C}_{139} \mathrm{H}_{180} \mathrm{~N}_{62} \mathrm{O}_{35}[$ Predicted +1$]=3278.42$ Observed: 3278.72

PNA $6 \mathrm{C}_{139} \mathrm{H}_{180} \mathrm{~N}_{62} \mathrm{O}_{35}$ [Predicted+1] = 3278.42 Observed: 3277.45

\section{Thermal Melting Analysis}

Oligonucleotides were purchased from Integrated DNA Technologies, Inc. (IDT) and were dissolved in autoclaved deionized water. Concentrations of oligonucleotide and PNA solutions were determined by UV absorption at $260 \mathrm{~nm}$ on an Agilent $8453 \mathrm{UV} / \mathrm{Vis}$ spectrometer equipped with an Agilent 89090A peltier temperature controller. Extinction coefficients for PNA were calculated using the nearest neighbor method. ${ }^{5}$ Extinction coefficients for oligonucleotides were reported by the supplier (IDT). Solutions of 1:1 oligonucleotide:PNA were prepared in $\mathrm{pH}=7.0$ buffer consisting of $10 \mathrm{mM}$ sodium phosphate, $0.1 \mathrm{mM}$ EDTA, and $150 \mathrm{mM} \mathrm{NaCl}$. Strand concentrations were $5 \mu \mathrm{M}$ in each component. The solutions were degassed under vacuum for 1-2 minutes prior to melting analysis. Thermal denaturation profiles (absorbance vs. temperature) of the hybrids were measured at $260 \mathrm{~nm}$ with a diode array UV/Vis spectrophotometer equipped with a Peltier 
temperature controller that is interfaced to a personal computer. For the temperature range $90{ }^{\circ} \mathrm{C}$ to $5{ }^{\circ} \mathrm{C}$, UV absorbance was recorded at $260 \mathrm{~nm}$ every $1{ }^{\circ} \mathrm{C}$, with an equilibration time of $60 \mathrm{~s}$ for each measurement point. A cooling profile was recorded for each complex. All samples were run in duplicate. The melting temperature $\left(T_{\mathrm{m}}\right)$ was determined from the maximum of the first derivative of the cooling curves and reported as the average of the two runs.

\section{Fluorescent Studies}

Fluorescent studies were performed on a SPEX Fluoromax fluorimeter using an ozone free xenon lamp. All samples were excited at $340 \mathrm{~nm}$ and the emission was monitored from 400-600 nm. Solutions of 1:1 oligonucleotide:PNA were prepared in $\mathrm{pH}=7.0$ buffer consisting of $10 \mathrm{mM}$ sodium phosphate, $0.1 \mathrm{mM}$ EDTA, and $150 \mathrm{mM} \mathrm{NaCl}$. Strand concentrations were $5 \mu \mathrm{M}$ in each component. All samples were heated to $90{ }^{\circ} \mathrm{C}$ for 5 minutes and cooled to room temperature slowly. All samples were run in duplicate and gave consistent results.

\section{References}

1. Pangborn, A. B.; Giardello, M. A.; Grubbs, R. H.; Rosen, R. K.; Trimmers, F. J. Organometallics 1996, 15, 1518.

2. Thompson, S. A.; Josey, J. A.; Cadilla, R.; Gaul, M. D.; Hassman, F.; Luzzio, M. J.; Pipe, A. J.; Reed, K. L.; Ricca, D. J.; Wiethe, R. W.; Noble, S. A. Tetrahedron 1995, 51, 6179. 3. Kaiser, E.; Colescott, R. L.; Bossinger, C. D.; Cook, P. I. Anal. Biochem. 1970, 34, 595.

4. Koch, T.; Hansen, H. F.; Andersen, P.; Larsen, T.; Batz, H. G.; Otteson, K.; Orum, H. J. Pept. Res. 1997, 49, 80.

5. Warshaw, M. M.; Tinoco, I., Jr. J. Mol. Biol. 1966, 20, 29. 